\title{
UJI DAYA KECAMBAH BERBAGAI JENIS VARIETAS JAGUNG ( Zea Mays) DENGAN MENGGUNAKAN METODE YANG BERBEDA
}

\section{SEED GERMINATION TEST OF CORN (Zea mays) VARIETIES USING DIFFERENT METHODS}

\author{
Nurhafidah $^{1)}$, Abdul Rahmat ${ }^{1)}$,Abbas Karre ${ }^{1)}$, Hasyim H. Juraeje ${ }^{1)}$ \\ 1) Program Studi Budidaya Tanaman Perkebunan, Jurusan Budidaya Tanaman Perkebunan, \\ Politani Pangkep \\ Jln. Poros Makassar-Pare KM. 83 Kec. Mandalle \\ Korespondensi : nurhafidah29@gmail.com
}

\begin{abstract}
ABSTRAK
Tujuan penelitian ini adalah untuk mengkaji metode pengecambahan terbaik terhadap daya berkecambah berbagai jenis varietas jagung. Penelitian ini di laksanakan di laboratorium Teknologi Benih Jurusan Budidaya Tanaman Perkebunan di Politenik Pertanian Negeri Pangkep pada Agustus hingga November 2020. Metode yang akan gunakan dalam penelitian ini adalah Pengecambahan benih dengan substrat kertas merang yaitu: Uji di atas kertas (UAK), Uji antara kertas (UDK), dan Uji kertas digulung didirikan dalam plastik (UKDdP) di dalam alat pengecambah (seed germinator). Penelitian ini menggunakan Rancangan Acak Lengkap (RAL) dalam faktorial 2 faktor yaitu; faktor pertama adalah varietas terdiri atas 3 taraf yaitu varietas Anoman( v1), varietas Bisma (v2), dan varietas Srikandi (v3,) dan faktor ke dua terdiri atas 3 taraf yaitu UAK (M1), UDK (M2), dan UKDdP (M3), masing-2 ulangan. Daya berkecambah pada uji UAK relatif sama, sedang pada UDK,UKDdP menunjukkan rata-rata daya berkecambah relatif lebih variatif. Rata-rata persentase daya berkecambah pada metode yang diuji berkisar 85,3 - 91,3 $\%$ untuk semua varitas yang diuji. Rata-rata daya kecambah jagung metode UDK sebesar 88,67 \pm $2,17 \%$, metode UDK $85,3 \pm 4,45 \%$ dan UKDdP $91,3 \pm 3,78 \%$. Metode pengecambahan, varietas jagung, dan interaksi antara metode pengecambahan dengan varietas jagung tidak menunjukkan perbedaan pengaruh terhadap daya berkecambah benih jagung $(\mathrm{P}>0,05)$. Hasil penelitian ini mengindikasikan bahwa pengecambahan benih jagung dengan metode UAK, UDK, dan UKDdP memiliki kapasitas yang sama terhadap daya berkecambah benih jagung.
\end{abstract}

Kata kunci: Daya berkecambah,benih jagung, kertas merang, seed germinator

\section{ABSTRACT}

The purpose of this study was to assess the best method on germination of corn varieties. This research was carried out in the Seed Technology Laboratory of the Department of Plantation Crops Cultivation at Pangkep State Polytechnic of Agriculture from August to November 2020. The germination method in this research was to use a straw paper substrate that was on top paper (UAK), between paper (UDK), and rolled paper that setting up in plastic (UKDdP) tests in a seed germinator. This study used a factorial completely randomized design (CRD) with 2 factors. The first factor is corn varieties consisting of three levels, namely Anoman (v1), Bisma (v2), and Srikandi (v3) varieties, and the second factor consists of 3 levels of germination methods, namely 
UAK (M1), UDK (M2), and UKDdP ( M3) with two replicates. The germination capacity in the UAK test was relatively the same, while at UDK, UKDdP showed that the average germination capacity was relatively more varied. The average percentage of germination in the tested methods ranged from 85.3 to $91.3 \%$ for all varieties tested. The average germination capacity of corn with the UDK method was $88.67 \pm 2.17 \%$, the UDK method was $85.3 \pm 4.45 \%$ and the UKDdP method was $91.3 \pm 3.78 \%$. The germination method, corn varieties, and the interaction between germination methods and corn varieties did not show any difference in effect on corn seed germination $(\mathrm{P}>0.05)$. The results of this study indicated that corn seed germination using the UAK, UDK, and UKDdP methods had the same capacity for the germination capacity of corn seeds.

Key words: Germination, corn seeds, paper straw, seed germinator

\section{PENDAHULUAN}

Jangung (Zea mays ) adalah salah satu tanaman penghasil karbohidrat yang terpenting duania, selain gandung dan padi. Bagi penduduk Amerika Tengah dan Selatan, bulir jagung adalah makanan pokok.sebagaimana bagi sebagian penduduk Afrika dan beberapa daerah diIndonesia menggunakan jagung sebagai pangan pokok. Selain sebagai sumber karbohidrat,jagung juga di tanam sebagai pakan ternak.

Jagung merupakan salah satu serealia yang strategis dan bernilai ekonomi serta mempunyai peluang untuk dikembangkan karena kedudukannya sebagai sumber utama karbohidrat dan protein setelah beras juga sebagai sumber pakan (Purwanto, 2008). Upaya peningkatan produksi jagung masih menghadapi berbagai masalah sehingga produksi jagung dalam negeri belum mampu mencukupi kebutuhan nasional (Soerjandono, 2008). Prospek usaha tani tanaman jagunng cukup cerah bila di kelolah secara intensif dan komersial berpola angribisnis. Permintaan pasar dalam negeri dan peluang ekspor komoditas jagung cenderung meningkat dari tahun ketahun, baik untuk memenuhi kebutuhan pangan maupun nonpangan.

Produksi tanaman jagung dapat di pengaruhi beberapa faktor yaitu belum optimalnya penyebaran varietas unggul di masyarakat, pemakaian pupuk yang belum tepat, penerapan teknologi dan cara bercocok tanam yang belum di perbaiki. Usaha untuk meningkatkan produksi tanaman jagumg adalah meningkatkan taraf hidup petani dan memenuhi kebutuhan pasar maka perlu meningkatkan produksi jagung yang memenuhi standar baik kwualitas maupun kuantitas jagung yang di hasilkan tetapi dalam melakukan hal tersebut perlu mengetahui atau memahami 
karakteristik tanaman jagung yang akan di tanam seperti morfologi, fisiologi dan agroteknologi oleh tanaman jagung sehingga dapat meningkatkan produksi jagung di Indonesia.

Pengujian benih dalam kondisi lapang biasa kurang memuaskan karena hasilnya tidak dapat diulang dengan konsisten. Karena itu pengujian dilaboratorium dilaksanakan dengan mengendalikan faktor lingkungan agar mencapai perkecambahan yang paling teratur, cepat dan lengkap bagi kebanyakan contoh benih. Ada bermacam-macam metode uji perkecambahan benih yang dapat digunakan untuk mengecambahkan bening yang dapat menunjang produktivitas. Setiap metode memiliki kekhususan tersendiri sehubungan dengan jenis benih yang diuji, jenis alat pengecambahan yang di gunakan, dan jenis parameter viabilitas yang di nilai

Perkecambahan merupakan tahap awal perkembangan suatu tumbuhan, khususnya tumbuhan berbiji. Dalam tahap ini, embrio di dalam biji yang semula berada pada kondisi dorman mengalami sejumlah perubahan fisiologis yang menyebabkan ia berkembang menjadi tumbuhan muda. Tumbuhan muda ini dikenal sebagai kecambah. (Sudjadi, 2006) memberikan penjelasan tentang perkecambahan,yaitu :Perkecambahan adalah proses pertumbuhan embrio dan komponenkomponen biji yang memiliki kemampuan untuk tumbuh secara normal menjadi tumbuhan baru. Komponen biji tersebut adalah bagian kecambah yang terdapat di dalam biji, misalnya radikula dan plumula. Daya berkecambah benih merupakan salah satu indikator viabiltas benih yang mengindikasikan kualitas benih. Penilaian perkecambahan dapat dilakukan dengan metode langsung yaitu penilaian yang dilakukan terhadap setiap individu benih dan metode tidak langsung yang penilaiannya dilakukan pada sekelompok benih.

Daya berkecambah benih yang merupakan salah satu tolak ukur viabilitas benih sangat tergantung pada kondisi lingkungan. Viabilitas benih tersebut dapat dikelompokkan berdasarkan kesesuaian lingkungannya yaitu viabilitas benih dalam lingkungan sesuai (favourable) dan viabilitas benih dalam lingkungan tidak sesuai (unfavourable). Lingkungan eksternal yang sangat menentukan kapasitas daya berkecambah sebagai indikator viabilitas benih adalah substrat pengujian. Substrat pengujian tersebut dapat berupa substrat alami (tanah, pasir, pasir kwarsa, pasir kali, bata merah) dan substrat buatan/kertas (towel, kimpak, blue blotter, kertas merang). Substrat pengujiaan harus memiliki persyaratan, tidak mudah robek, steril, tidak toksik, dapat menyerap air, warna memudahkan pengujian. 
Salah satu substrat yang sering digunakan sebagai media perkecambahan adalah kertas merang yang dapat digunakan dengan berbagai metode uji. Hingga saat ini belum ada informasi ilmiah yang mengungkap pengaruh beberapa metode uji yang menggunakan substrat kertas merang yang diujikan pada berbagai varietas benih jagung terhadap daya berkecambah benih. Berdasarkan latar belakang diatas telah dilakukan penelitian viabilitas beberapa jenis varietas jagung dengan menggunaan metode uji yang berbeda untuk mengetahui metode yang terbaik dalam perkecambahan berbagai jenis varietas jagung. Pada penelitian ini di gunakan metode uji daya perkecambahan benih yang menggunakan media kertas merang.

\section{BAHAN DAN METODE}

Benih jagung yang digunakan dalam penelitian ini terdiri dari 3 (tiga) varietas yaitu Anoman, Bisma, dan Sriandi. Perkecambahan jagung tersebut dilakukan pada media tumbuh kertas merang sebagai substrat. Kertas merang yang merupakan kertas yang terbuat dari bahan merang atau jerami dipilih sebagai substrat karena memiliki daya absorpsi air yang tinggi dan harganya murah serta sangat praktis untuk mendapatkan kondisi yang terkontrol dan jauh lebih sedikit ruang yang diperlukan untuk menempatkan materi yang diuji. Untuk menjaga kondisi lingkungan agar sesuai dengan kebutuhan perkecambahan maka digunakan seed germinator. Alat yang dilengkapi dengan pengatur suhu dan intensitas cahaya ini dapat diatur dan disesuaikan dengan kebutuhan lingkungan yang optimal untuk perkecambahan jagung.

Penelitian ini menggunakan Rancangan Acak Lengkap (RAL) pola faktorial 3 x 3 x 2 . Faktor pertama adalah faktor varietas jagung yang terdiri dari tiga taraf $(\mathrm{v} 1=$ Anoman, $\mathrm{v} 2=$ Bisma, v3 = Srikandi, ) dan faktor ke dua adalah metode perkecambahan terdiri atas 3 taraf $(\mathrm{M} 1=$ Metode Uji di atas Kertas, M2 = Metode Uji Di antara Kertas, M3 = Metode Uji Kertas Digulung Didirikan Dalam Plastik). Setiap perlakuan diulang 2 kali sehingga terdapat 18 plot pengamatan.

Perkecambahan dengan tiga metode berbeda dilakukan dengan menggunakan 3-4 lembar kertas merang lembab sebagai substrat dan diletakkan di atas talang plastik. Setiap metode uji menggunakan 25 butir benih jagung untuk dikecambahkan. Metode Uji di atas Kertas (UDK) dilakukan dengan meletakkan butiran benih jagung di atas substrat dan disusun secara teratur. Metode Uji Di antara Kertas (UAK ) dilakukan dengan melipat subtrat ke arah panjang kertas sehingga memberi bekas lipatan pada setegah bagiannya, benih jagung di atas subtrat disusun secara teratur dalam lima baris, masing - masing 5 butir di atas setengah bagian kertas dan 
setengah bagian subtrat yang tidak di tanami dilipat sehingga menutupi benih, kemudian ketiga tepi kertas yang belum terlipat dilipat ke arah atas. Uji Kertas Digulung Didirikan dalam Plastik (UKDdP) dilakukan dengan menghamparkan selembar plastik transparan tipis di atas meja dan kertas merang lembab diletakkan terhampar di atas lembaran plastik tadi. Butiran benih diletakakan secara teratur dengan jarak satu sama lain kurang lebih $1 \mathrm{~cm}$ dan ditutup dengan 2 3 lembar kertas merang lembab lainnya. Materi pengujian tersebut selanjutnya digulung ke arah panjang substrat. Materi pengujian kertas merang yang telah berisi benih jagung dari ketiga metode yang diujikan ditempatkan di dalam seed germinator (alat pengecambah) dan selanjutnya dilakukan pengaturan suhu dan intensitas cahaya sesuai kebutuhan optimal untuk perkecambahan jagung.

Parameter penelitian berupa bentuk-bentuk kecambah normal diamati pada umur 3 dan 5 hari setelah tanam (HST). Kecambah-kecambah abnormal dan busuk yang ditemukan pada pengamatan pertama dibuang. Pada umur 5 HST, jumlah kecambah pada setiap metode dihitung untuk selanjutnya dihitung daya kecambahnya. Daya kecambah dihitung dengan menggunakan formula:

$$
\text { Daya Kecambah }(\%)=\frac{\text { Jumlah benih berkecambah normal }}{\text { Jumlah benih yang dikecambahkan }} \times 100 \%
$$

Untuk mengetahui pengaruh metode perkecambahan dan varietas jagung terhadap daya kecambah maka data daya kecambah jagung dianalisis dengan analisis sidik ragam (analysis of variance, Anova) dalam Rancangan Acak Lengkap. Jika metode perkecambahan dan varietas jagung menunjukkan pengaruh yang berbeda maka dilanjutkan dengan uji perbandingan berganda Duncan. Perbedaan secara statistik setiap perbandingan dilakukan pada taraf nyata $95 \%$ (P < 0,05). Analisis data dilakukan dengan bantuan software Microsoft Excel 2016.

\section{HASIL DAN PEMBAHASAN}

Daya kecambah jagung yang diukur melalui persentase perkecambahan (\%) menunjukkan respon tertinggi pada kombinasi perlakuan antara metode Uji Kertas Digulung Didirikan Dalam Plastik (M3) dengan varietas jagung Srikandi (V3). Respon daya kecambah terendah ditemukan pada perlakuan metode Uji Di atas Kertas (M2) dengan varietas jagung Bisma (V2). Daya kecambah ketiga varietas jagung yang dikecambahkan dengan metode uji di atas kertas relatif 
sama, sedangkan yang dikecambahkan dengan metode uji di antara kertas dan metode uji kertas digulung dalam plastik cenderung lebih variatif. Rata-rata persentase daya berkecambah pada ketiga metode uji berkisar 85,3-91,3\% (Gambar 1) untuk semua varitas yang diuji dan rata-rata persentase daya berkecambah pada ketiga varietas uji berkisar 84,67 - $94 \%$ untuk semua metode yang diuji (Gambar 2). Rata-rata daya kecambah jagung metode UDK sebesar $88,67 \pm 2,17 \%$, metode UDK 85,3 \pm 4,45 \% dan UKDdP 91,3 $\pm 3,78 \%$. . Rata-rata daya kecambah jagung varietas Anoman sebesar 84,67 $\pm 4.06 \%$, varietas 86,67 $\pm 3,04 \%$ dan UKDdP 94,0 $\pm 2,88 \%$. Sedangkan rata-rata persentase daya berkecambah interaksi metode perkecambahan dengan varietas berkisar $74-98 \%$ (Gambar 3).

Hasil analisis sidik ragam menunjukkan perlakuan metode perkecambahan, varietas jagung, dan interaksi antara metode perkecambahan dengan varietas tidak memberi pengaruh yang berbeda nyata $(P>0,05)$. Hal ini mengindikasikan penerapan metode perkecambahan terhadap varietas benih jagung uji, baik efek tunggal maupun interaksi memberi pengaruh daya berkecambah yang sama. Dengan demikian metode perkecambahan dalam mengecambahkan jagung dapat menggunakan salah satu di antara ketiga metode uji dengan hasil sama. Pemilihan metode yang akan diterapkan dapat mempertimbangkan kemudahan, efisiensi, dan kebiasaan karena ketiga metode yang diuji tidak memperlihatkan kapasitas yang berbeda terhadap daya berkecambah benih jagung.

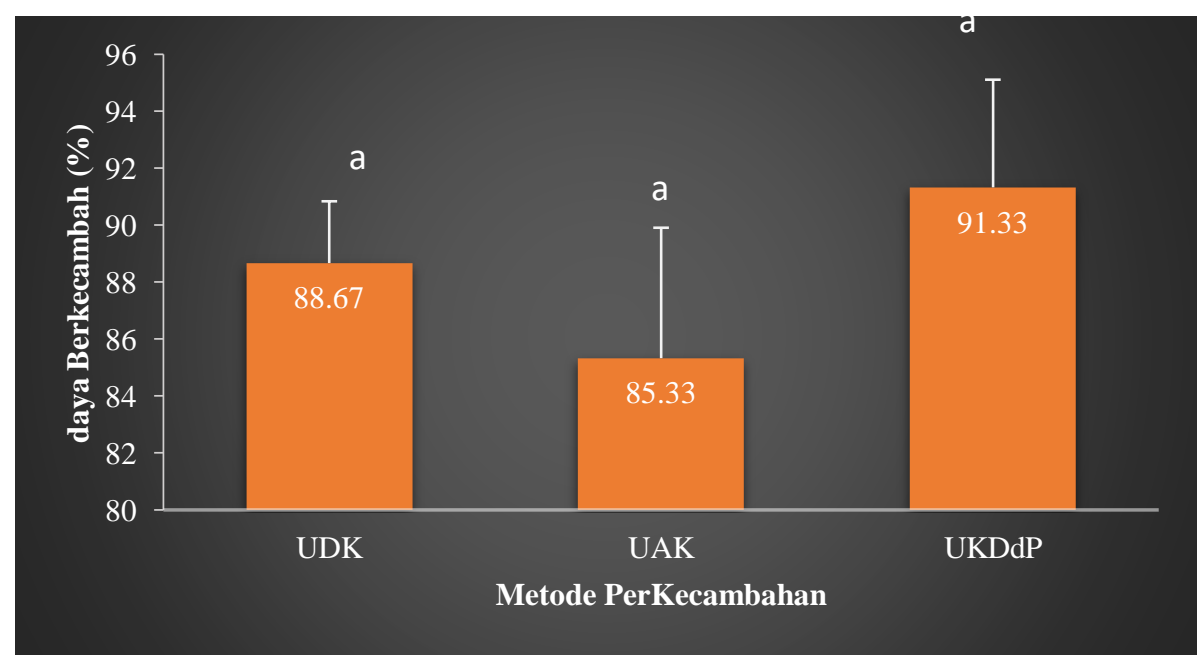

Gambar 1. Rata - rata daya berkecambah ( \% ) benih jagung dengan menggunakan Uji UDK, Uji UAK, dan Uji UKDdP lima Hari Setelah Tanam (HST). Bar vertikal menunjukkan Rata-rata \pm SE. Huruf yang sama di atas bar menunjukkan tidak ada perbedaan nyata $(\mathrm{P}>0,05)$ 


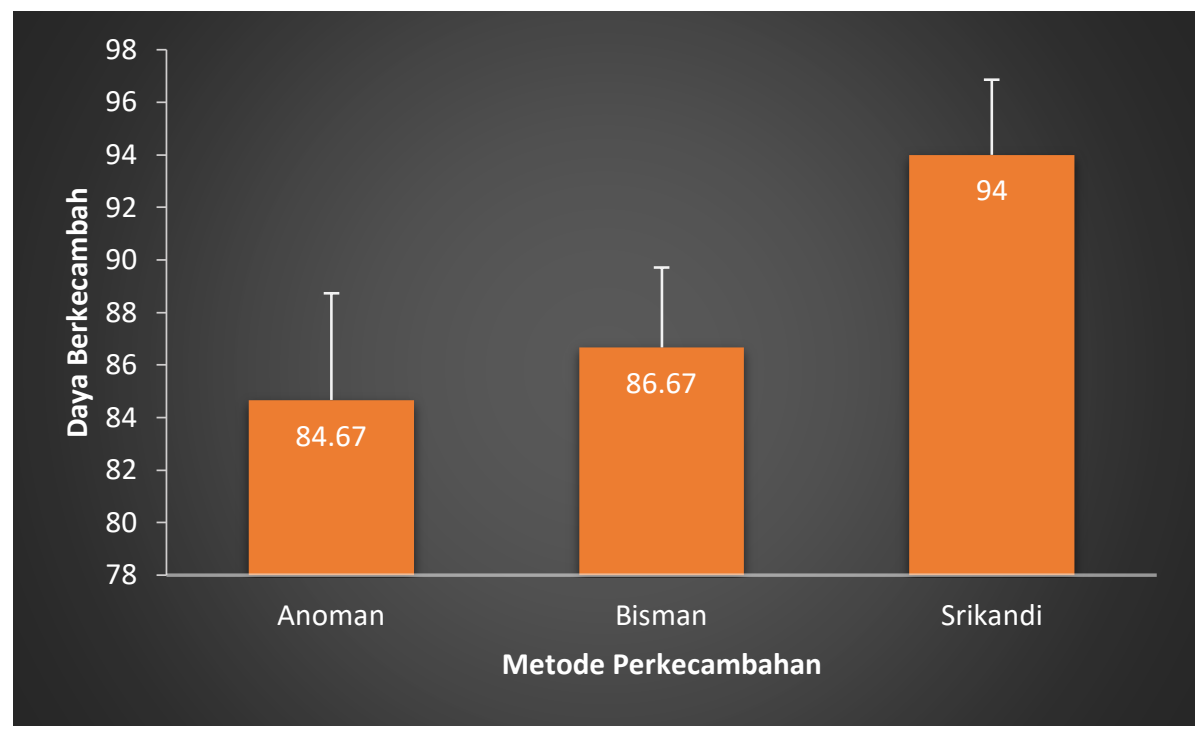

Gambar 2. Rata - rata daya berkecambah ( \% ) benih jagung varietas Anoman, varietas Bisman, dan varietas Srikandi lima Hari Setelah Tanam (HST). Bar vertikal menunjukkan Rata-rata \pm SE. Huruf yang sama di atas bar menunjukkan tidak ada perbedaan nyata $(\mathrm{P}>0,05)$

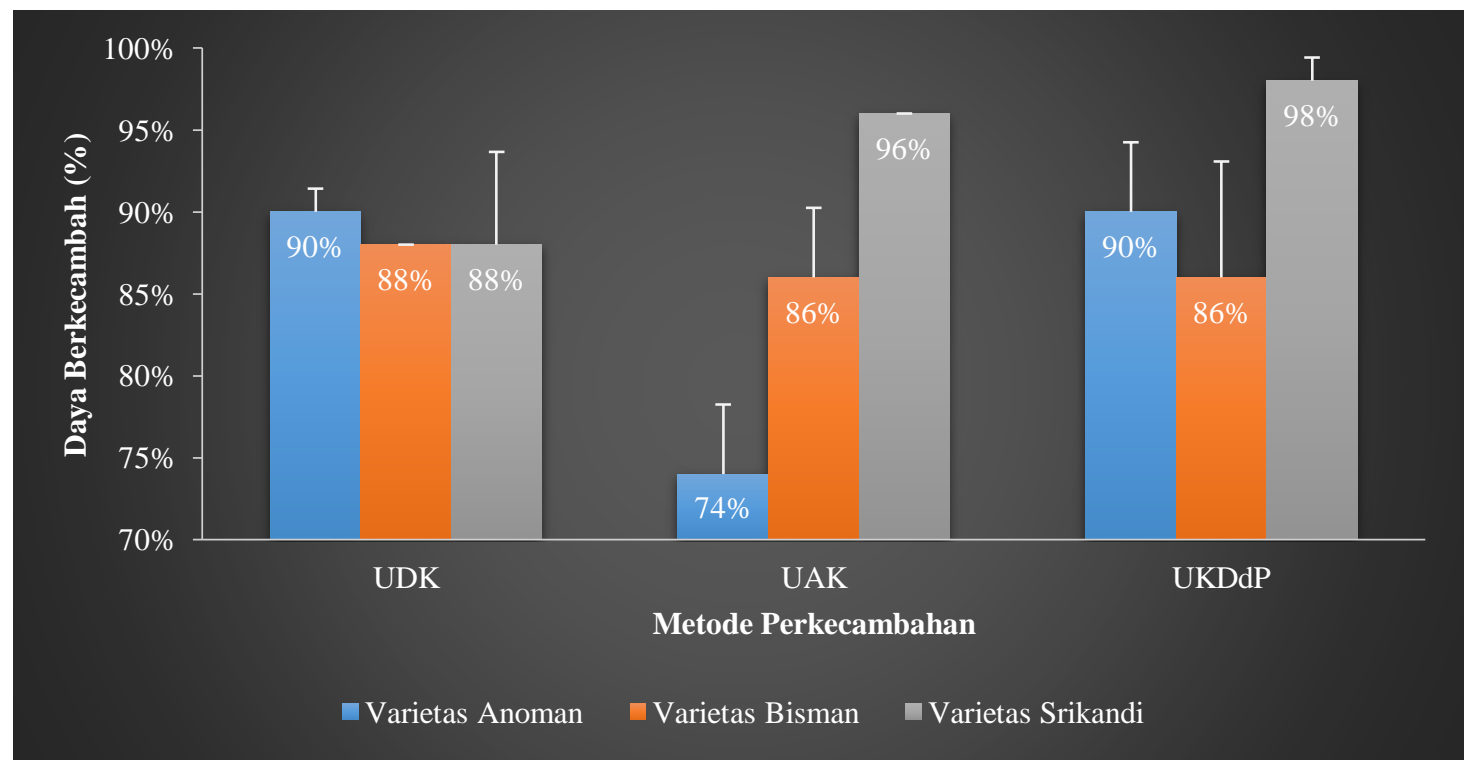

Gambar 3. Rata - rata daya berkecambah ( \% ) benih jagung interaksi metode Uji UDK, Uji UAK, dan Uji UKDdP terhadap varietas Anoman, varietas Bisman, dan varietas Srikandi lima Hari Setelah Tanam (HST). Bar vertikal menunjukkan Rata-rata \pm SE. Huruf yang sama di atas bar menunjukkan tidak ada perbedaan nyata $(\mathrm{P}>$ $0,05)$ 
Metode pengujian dengan menggunakan metode uji di atas kertas (UDK), uji di antara kertas (UAK), dan Uji kertas digulung didirikan dalam plastik yang memberi pengaruh yang sama terhadap daya kecambah benih jagung dapat disebabkan oleh kemampuan substrat yang mampu menyimpan air sehingga kelembaban substrat tetap terjaga. Disamping itu pengujian dilakukan menggunakan germinator sebagai tempat perkecambahan pada ketiga metode uji sehingga kondisi lingkungan relatif konstan sesuai pengaturan yang dilakukan. Kondisi lingkungan sebagai faktor eksternal yang terjaga dan relatif konstan tersebut memberi pengaruh yang sama terhadap daya kecambah benih jagung. Menurut (Kuswanto, 1996) perkecambahan benih di pengaruhi oleh faktor internal dan eksternal.

Daya berkecambah merupakan tolok ukur viabilitas potensial yang merupakan simulasi dari kemampuan benih untuk tumbuh dan berproduksi normal dalam kondisi optimum (Sadjad, 1993). ketiga metode uji perkecambahan UDK,UAK,UKDdP yang digunakan merupakan metode yang baik karna memberikan kondisi yang optimum bagi perkecambahan benih. Uji perkecambahan dapat di gunakan untuk mengetahuai kemampuan benih berkecambah maksimum pada kondisi optimum. Kecepatan tumbuh benih sangat terkait dengan persentase daya berkecambah benih. Perkecambahan benih merupakan suatu rangkain perubahan-perubahan morfologi, fisiologi dan biokimia sebagaimana dikemukakan oleh Copeland \& Mc Donald.(2001) yang menyataan bahwa perkecambahan benih secara fisiologi muncul dan perkembangnya struktur-struktur dari emberio benih sampai dengan akar menembus kulit biji.

Persentase daya berkecambah benih merupakan jumlah proporsi benih-benih yang telah menghasilkan perkecambahan dalam kondisi dan periode tertentu. Persentase kecambah normal yang dapat dihasilkan oleh benih murni pada kondisi yang menguntungkan dalam jangka waktu yang sudah ditetapkan. Bila daya uji kecambah benih memberikan hasil yang negatif maka perlu diadakan usaha lain untuk mengetahui faktor apakah yang mengakibatkan kegagalan perkecambahan. Prosedur uji daya kecambah benih dilakukan dengan menjamin agar lingkungan menguntungkan bagi perkecambahan seperti ketersediaan air, cahaya, suhu dan oksigen.

Daya kecambah benih memberikan informasi kepada pemakai benih akan kemampuan benih tumbuh normal menjadi tanaman yang berproduksi wajar dalam kondisi biofisik lingkungan yang optimal. Uraian kriteria kecambah normal dan abnormal. Kecambah normal, kecambah yang memiliki semua struktur kecambah penting yang berkembang dengan baik, seperti akar semi 
primer dan semi skunder terlihat jelas. Kecambah memiliki perkembangan sistem perakaran yang baik, terutama akar primer dan akar seminal paling sedikit dua. Perkembangan hipokotil baik dan sempurna tanpa ada kerusakan pada jaringan. Pertumbuhan plumula sempurna dengan daun hijau tumbuh baik. Epikotil tumbuh sempurna dengan kuncup normal. Memiliki satu kotiledon untuk kecambah dari monokotil dan dua bagi dikotil. Sedangkan kecambah abnormal, kecambah yang tidak memperlihatkan potensi untuk berkembang menjadi kecaambah normal. Yang tergolong kecambah tidak normal seperti, kecambah rusak, kecambah cacat atau tidak seimbang, kecambah busuk dan kecambah lambat. Kecambah rusak tanpa kotiledon, embrio yang pecah dan akar primer pendek. Kecambah yang bentuknya cacat, perkembangan lemah atau kurang seimbang dari bagian-bagian penting. Plumula yang terputar, hipokotil, epikotil, kotiledon yang membengkak, akar yang pendek. Koleoptil yang pecah atau tidak mempunyai daun : kecambah yang kerdil. Kecambah yang tidak membentuk klorofil dan kecambah yang lunak. Untuk benih pohon-pohonan bila dari micropyl keluar daun dan bukanya akar.

\section{KESIMPULAN}

Berdasarkan hasil yang diperoleh dalam penelitian ini maka dapat disimpulkan bahwa metode perkecambahan Uji Di atas kertas, Uji di antara kertas, dan Uji Kertas Digulung Didirikan dalam Plastik menghasilkan daya berkecambah yang sama terhadap benih jagung varietas Anoman, varietas Bisman, dan Varietas Srikandi.

\section{UCAPAN TERIMA KASIH}

Terimah kasih disampaikan kepada Direktur Politeknik Pertanian Negeri Pangkep yang telah menyiapkan pembiayaan penelitian ini melalui dana PNBP Politani Pangkep Tahubn 2020. Terimah kasih pula disampaikan kepada ketua PPPM yang telah menfasilitasi pelaksanaan penelitian untuk Pranata Laboratorium Pendidikan Politeknik Pertanian Negeri Pangkep. Serta ucapan terima kasih kepada seluruh rekan - rekan yang telah membantu jalannya penelitian ini.

\section{DAFTAR PUSTAKA}

Copeland, L. O., \& Mc Donald., M. B. (2001). Principles of Seed Science and Technology. Burgess Publishing Company.

Kuswanto, H. (1996). Dasar-dasar teknologi, produksi, dan sertifikasi benih. Andi offset. 
Purwanto, S. (2008). Perkembangan Produksi dan Kebijakan dalam Peningkatan Produksi Jagung. Direktorat Budi Daya Serealia, Direktorat Jenderal Tanaman Pangan.

Sadjad, S. (1993). Dari benih kepada Benih. PT Gramedia Widiasarana Indonesia.

Soerjandono, N. B. (2008). Teknik Produksi Jagung Anjuran di Lokasi Peima Tani Kabupaten Sumenep. Buletin Teknik Pertanian.

Sudjadi, B. (2006). BiologiSainsdalamKehidupan. Yudhistira, Surabaya. 